\title{
ADOPTION OF IRRIGATION TECHNOLOGY TO COMBAT HOUSEHOLD FOOD INSECURITY IN THE RESOURCE-CONSTRAINED FARMING SYSTEMS OF THE EASTERN CAPE PROVINCE, SOUTH AFRICA
}

\author{
Christian, M. ${ }^{1}$, Obi, A. ${ }^{2}$ and Agbugba, I. K. ${ }^{3}$ \\ Correspondence Author: M. Christian. E-mail: mzuyanda1990@gmail.com
}

\begin{abstract}
Sustainable water management has been identified as a powerful tool to combat persistent food insecurity in South Africa's poor rural communities. The irrigation revitalisation scheme was launched in the first decade of post-Apartheid South Africa and focused on smallholder farmers in the former homeland areas. However, the adoption of irrigation technology has been limited, while official data point to worsening poverty rates and food insecurity as agricultural output declines in the face of rising prices. There is thus strong policy interest to ascertain the circumstances in which irrigation adoption can be enhanced. A cross-sectional research design was utilised to collect data from 200 farmers (adopters and non-adopters) selected through a combination of purposive and stratified sampling methods. Probit regression results suggest that irrigation adoption is influenced by distance to the irrigation scheme, age of the farmer, family size, credit access, extension contact, and group membership. Water management programmes that address community access to irrigation water are likely to enhance adoption of irrigation technology, with credit access and extension provided to ensure sustainable use of the technology.
\end{abstract}

Keywords: Eastern Cape, Extension services, Food insecurity, Irrigation adoption, Smallholder farmers

\section{INTRODUCTION}

The South African National Water Policy (2013) is underpinned by three fundamental principles for managing water resources which include equity, environmental sustainability, and efficiency (Department of Water Affairs, 2013). According to the Department of Water Affairs (2013), the demand for water would have exceeded supply in Gauteng in 2013, and in the whole of South Africa by 2025. This implies that water use in agriculture needs to improve in order to preserve the resource which is fast declining in South Africa. Irrigation is an ageold means of increasing agricultural productivity. It expands the arable area, improves yield and increases cropping frequency, sometimes enabling two or three crops a year. South African smallholder irrigation schemes are multi-farmer irrigation projects larger than 5 ha in size that were either established in the former homelands or in resource-poor areas by black people or agencies assisting them (Van Averberke \& Mohammed, 2006). However, most farmers on irrigation schemes still operate plots below 2.5 ha. In South Africa, 1.5\% of the land is under irrigation and producing 30\% of the crops in the country (Statistics South Africa, 2008).

\footnotetext{
${ }^{1}$ Department of Agricultural Economics and Extension, North-West University, Private Bag X2046, Mmabatho 2735, South Africa. Email: mzuyanda1990@gmail.com

${ }^{2}$ Department of Agricultural Economics and Extension, University of Fort Hare, Private Bag X1314, Alice 5700, South Africa. Email: aobi@ufh.ac.za

${ }^{3}$ Department of Agricultural Economics and Extension, University of Fort Hare, Private Bag X1314, Alice 5700, South Africa. Email: iagbugba@ufh.ac.za
} 
S. Afr. J. Agric. Ext.

Vol. 47 No. 2, 2019: 94 - 104

http://dx.doi.org/10.17159/2413-3221/2019/v47n2a506
Christian, Obi

Agbugba

(License: CC BY 4.0)

According to Backeberg and Sanewe (2006), approximately 1.3 million hectares are under irrigation with 0.1 million hectares being in the hands of smallholders. Gibb (2004) counted 287 smallholder irrigation schemes in South Africa covering between 46000 ha and 49500 ha. Denison and Manona (2007) found a total of 302 smallholder irrigation schemes in the country. Out of these, 90 schemes were non-operational, 206 schemes were operational, and 6 schemes could not be accounted for due to data limitations. Land under smallholder irrigation was held by approximately 31000 farmers who constitute $15 \%$ of the total smallholder population. By comparison, 1.2 million hectares of irrigation schemes under large-scale commercial farmers are in the hands of about 28350 farmers (Backeberg \& Sanewe, 2006).

Smallholder farming plays an important role in the national economy of many countries, especially less developed ones. According to Delgado (1999), in sub-Saharan Africa, smallholder farming accounts for $70 \%$ of total employment, $40 \%$ of total merchandise exports, and $33 \%$ of gross domestic product (GDP). However, the erratic rainfall experienced by most regions implied the unreliability of rain-fed smallholder farming. Therefore, to alleviate the impact of droughts on crop production, irrigation was developed and adopted in many countries (Freeman \& Silim, 2001). In Asia, investment in irrigation was a key ingredient of the Green Revolution which created conducive conditions for industrial and economic development (Turral, Svendsen \& Faures, 2010). A similar development trajectory for South Africa and other parts of sub-Saharan Africa was seen as viable (Lipton, 1996). Irrigation can lead to a reduction in crop production risk and hence provides greater incentives to increase input use, increase crop yields, intensify crop production, and diversify into higher-valued crops. Consequently, the increase in marketable surplus and commercial activities has the potential to generate increased incomes for farmers (Asayehegn, Yirga \& Rajan, 2011).

Recent research on small-scale irrigation schemes are now asking questions about how these schemes impact livelihoods. The schemes entail considerable investments of resources to improve the livelihoods of the poor. The emphasis of the United Nation's Millennium Development Goals (MDGs) of reducing poverty and improving livelihoods has often meant that considerable attention is paid to the outcomes without as much attention being paid to the extent to which the process might be constrained by availability of resources and even the nature of the resources at the disposal of the recipients of the support services under these schemes. The observed slow pace of the transformation in many contexts, and the fact that in many cases negative results have been realised, are forcing researchers to re-think the whole basis of the research and policy work that inform interventions. A major driver of this new thinking draws support from the theories on poverty and access to benefit from resources as elaborated by Sen (1981) as well as Ribot and Peluso (2003) to compel consideration of whether access to resources plays a crucial role in whether livelihood benefits are realised. There is now growing interest on sustainable management of the natural resource base of the community as well as their relationships and interactions with other resources and assets in the environment of the small farmer.

However, there is a concern that after more than two decades of implementing various reform measures, small-scale farming practiced in the former independent homelands remains virtually stagnant. Reasons for this are difficult to pinpoint in the quite crowded terrain of farmer support initiatives. In a study conducted in the Eastern Cape, Muchara (2011) observed instances of sub-optimal water utilisation regimes on irrigation schemes as well as individual plots, suggesting that the problem is not solely one of insufficient access. Since, among all the technologies on offer, irrigation is non-negotiable in the light of South Africa's semi-arid 
S. Afr. J. Agric. Ext.

Vol. 47 No. 2, 2019: 94 - 104

http://dx.doi.org/10.17159/2413-3221/2019/v47n2a506
Christian, Obi

Agbugba

(License: CC BY 4.0)

status, the present study zeroes in on this technology to ascertain the grounds on which farmers can step up productive water utilisation.

\section{OBJECTIVES OF THE STUDY}

In light of the foregoing, the objective of the study was to ascertain the circumstances in which irrigation technology adoption can be enhanced to combat household food insecurity in the Eastern Cape Province of South Africa. More specifically, the study aimed to:

1. Examine and describe the socio-economic factors of adopters and non-adopters in the study area.

2. Investigate factors affecting irrigation adoption by smallholder farmers.

\section{MATERIALS AND METHODS}

\subsection{Study areas}

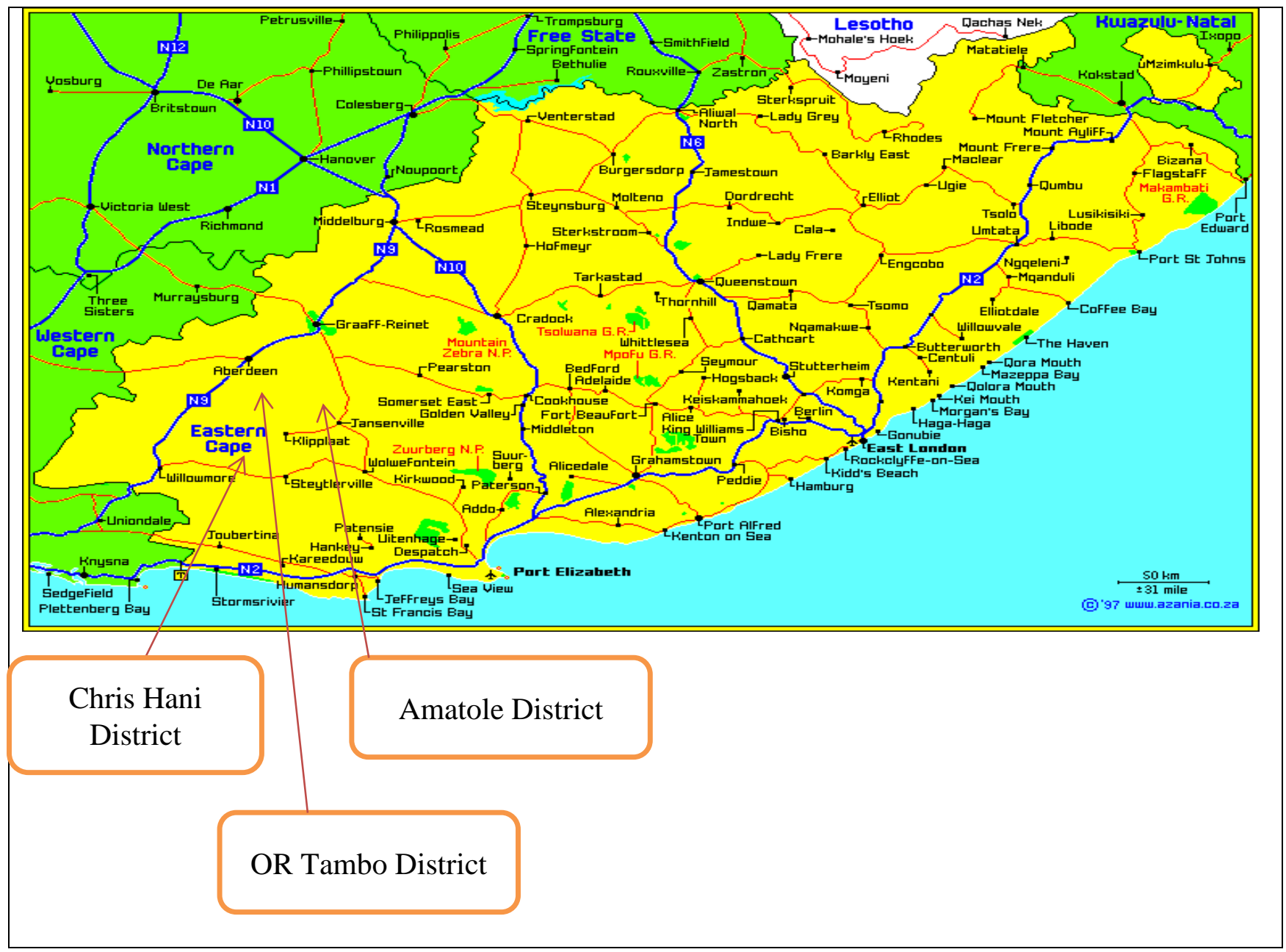

Figure 1: Map of the study areas

Source: Google maps, 2016

The Eastern Cape Province is easily poorest, the situation being worse in the former homelands of Transkei and Ciskei (Jacobs, 2010). The province's average poverty level was estimated at 
S. Afr. J. Agric. Ext.

Vol. 47 No. 2, 2019: 94 - 104

http://dx.doi.org/10.17159/2413-3221/2019/v47n2a506
Christian, Obi

Agbugba

(License: CC BY 4.0)

$74.9 \%$ in four districts which include O.R. Tambo, Alfred Nzo, Joe Gqabi and Chris Hani. Unemployment rate stood at 35\% in 2016 and social grant recipients were substantial.

\subsection{Irrigation schemes}

\subsubsection{Qamata irrigation scheme}

Qamata irrigation scheme is located in Intsika Yethu Municipality, part of Chris Hani District in the Eastern Cape Province. In 1968, the construction of Lubisi dam was completed to serve Qamata irrigation scheme. Initially the scheme was divided into two portions, namely the individual food plots of 0.25 ha to 2.5 ha based on the size of land owned by the household before the establishment of the irrigation scheme. For each household that joined the scheme, their land tenure needed to be converted into communal land tenure systems administered by traditional leaders (Kodua-Agyekum, 2009). The second category of farmers was regarded as commercial farmers who owned land of more than 5 ha in size. In addition, a highly mechanised Lanti commercial farm was established on over 225 ha of land to create employment and generate income used to subsidize inputs for household food plots. The major crops grown on the Lanti commercial farm included maize, lucerne and cabbage. Lanti farm used a vertical integration approach, where most of the produce harvested was sorted, graded and carefully packed, ready to be sold in formal markets (Kodua-Agyekum, 2009). However, the scheme failed to realise its objectives of reducing poverty, increasing employment and improving the general livelihoods of farmers at the scheme (Kodua-Agyekum, 2009).

\subsubsection{Tyefu irrigation scheme}

Tyefu irrigation scheme is located $30 \mathrm{~km}$ in the western part of Peddi along banks of the lower Great Fish River in the Eastern Cape Province of South Africa (Sishuta, 2005). The scheme was using approximately $25 \mathrm{~km}$ of the Great Fish River waters that served five sections. These sections include Ndlambe, Pikoli, Ndwayana, Kaliken and Glenmore. In 1997, the scheme was reported to cover approximately 694 ha with a future potential of expansion to 1000 ha of irrigated land. The area is faced with multiple agricultural challenges which include intensive droughts, low soil fertility, irregular rain fall, poor water quality, high rates of evaporation, and extreme temperatures (Sishuta, 2005). Communities surrounding Tyefu irrigation scheme lack access to credit/ finance support and extension services, and are also challenged with poor infrastructures that limit movement of produce from farms to markets. Soil erosion and veld degradation makes land unsuitable for farming. Sishuta (2005) reported that Tyefu area has a potential of commercial crop production, though more suitable for extensive and semiintensive livestock production. Large blocks of uncultivated farmland can be observed in Tyefu communities, and this may be due to the aforementioned challenges that are beyond farmers' control (Sishuta, 2005).

\subsubsection{Ntshongweni irrigation scheme}

Ntshongweni irrigation scheme is located in Qumbu of the O.R. Tambo District Municipality in the Eastern Cape Province of South Africa. Qumbu is a rural town which is $61 \mathrm{~km}$ north of Mthatha. The scheme was initiated in 2013 by the smallholder farmers of Ntshongweni rural community. The scheme is about 30 ha owned and managed by community villagers. 
S. Afr. J. Agric. Ext.

Vol. 47 No. 2, 2019: 94 - 104

http://dx.doi.org/10.17159/2413-3221/2019/v47n2a506
Christian, Obi

Agbugba

(License: CC BY 4.0)

\subsubsection{Pendu irrigation scheme}

Pendu irrigation scheme is located in King Sabatha Dalindyebo Local Municipality in Mqanduli town. Mqanduli is situated about $30 \mathrm{~km}$ south of Mthatha. Pendu irrigation consists of 30 households farming on 58 ha for maize production. The scheme was initiated in 2013 by the Department of Agricultural Ministry under the leadership of Zoleka Chapa.

\subsection{Research design}

This study used a cross sectional survey design where data were collected at a single point in time. Qualitative and quantitative data were collected from the four irrigation schemes using a combination of methods such as a survey, focus groups and key informant interviews.

\subsection{Sampling technique and sample size}

A combination of purposive and stratified sampling techniques was used to select farmers in the study areas. The farmers were stratified into two strata, namely irrigation users and nonusers. From each stratum, random sampling was conducted to obtain 100 irrigators and 100 non-irrigators. Data collection was done through structured surveys using a close-ended questionnaire. Since the number of household heads in the two groups is proportional, an equal number of participants was drawn from each group, in other words, 100 household heads were selected from each group. In total, 200 household heads were interviewed.

\subsection{Empirical model for irrigation adoption}

Production risk factors are important in household decisions to adopt irrigation. This is because farmers in low income countries are risk averse (Dercon, 2004). The probit regression model was chosen as there is no rule compelling the choice of models (Gujarati, 2004). The general formula for the probit regression model is specified as:

$Y_{i}=\alpha_{0}+\alpha_{1} x_{i}+\alpha_{2} x_{i}+\alpha_{3} \mathrm{X}_{\mathrm{i}}+\alpha_{4} \mathrm{X}_{\mathrm{i}}+\alpha_{\mathrm{n}} \mathrm{X}_{\mathrm{n}}+\varepsilon$

Where, $\varepsilon \sim N(0,1)$

$Y_{i}$ is the dependent variable, is equal to one when a farmer adopted irrigation during 2014-2015 period, and equal to zero if the farmer did not. The constant or intercept term is depicted by $\alpha_{0}$ while $\alpha_{1}, \alpha_{2}, \alpha_{3}, \alpha_{4}$ and........ $\alpha_{n}$ represent the parameters to be estimated and $\varepsilon$ is the stochastic disturbance term. The probit regression model adds the condition of normally distributed variables that can be specified as:

$P\left(Y=\frac{1}{X}\right)=F(I i)=\frac{1}{\sqrt{2 \pi}} \int_{\alpha}^{J i} e^{\frac{-z^{2}}{2}} d z$

Where,

$\mathrm{I}_{i}=\alpha_{0}+\alpha_{1} x_{i} \ldots \ldots \ldots \ldots \ldots \ldots \ldots \ldots \ldots+\alpha_{\mathrm{n}} \mathrm{x}_{\mathrm{n}}=$ utility index (latent variable), $P\left(Y=\frac{1}{X}\right)=$ the probability of irrigation adoption; $\mathrm{Z}=$ the standard normal variable, and $\mathrm{F}$ is the standard normal CDF. Gujarati (2004) explains the behaviour of a dichotomous dependent variable as we need to use a suitable Cumulative distribution function (CDF). The independent variables that condition of adoption behaviour are age, gender, level of education, household size, farm 
S. Afr. J. Agric. Ext.

Vol. 47 No. 2, 2019: 94 - 104

http://dx.doi.org/10.17159/2413-3221/2019/v47n2a506
Christian, Obi

Agbugba

(License: CC BY 4.0)

size, off farm income, access to extension services, access to credit, primary occupation, member of a group, and distance to irrigation scheme.

\subsubsection{Definition of variables and hypotheses}

In this study, adoption of irrigation technology is the dependent variable calibrated as a binary response that is coded 1 if a farmer adopts and 0 otherwise. It is assumed that the household's behaviour is explained by different demographic, socio-economic and institutional factors. Variables explain adoption behaviour, how calibrated/ defined, and hypothesized relationship with dependent variable are presented in Table 1.

\section{Table 1: Variables included in the model}

\begin{tabular}{|c|c|c|}
\hline Variables & Definition & Hypothesized Sign \\
\hline Age $\left(X_{1}\right)$ & Actual number of years & + \\
\hline Gender $\left(\mathrm{X}_{2}\right)$ & $\begin{array}{l}\text { Gender of the farming } \\
\text { household head (Male }=1 \text {, } \\
\text { Female }=0 \text { ) }\end{array}$ & $+/-$ \\
\hline Marital status $\left(\mathrm{X}_{3}\right)$ & $\begin{array}{l}\text { Marital status of the farming } \\
\text { household head (Single }=1 \text {, } \\
\text { Married }=2 \text {, Divorced }=3 \text {, } \\
\text { Widowed }=4 \text { ) }\end{array}$ & + \\
\hline $\begin{array}{l}\text { Number of years spent at } \\
\text { school }\left(\mathrm{X}_{4}\right)\end{array}$ & $\begin{array}{l}\text { Education level of the } \\
\text { farming household head }\end{array}$ & + \\
\hline Household size $\left(\mathrm{X}_{5}\right)$ & Number of persons & + \\
\hline Farm size $\left(\mathrm{X}_{6}\right)$ & Number in hectares & \\
\hline $\begin{array}{l}\text { Other groups' membership } \\
\left(\mathrm{X}_{7}\right)\end{array}$ & $\begin{array}{l}\text { Member of community club } \\
(\text { Yes }=1, \text { No }=2)\end{array}$ & + \\
\hline Credit accessibility $\left(\mathrm{X}_{8}\right)$ & $(\mathrm{Yes}=1, \mathrm{No}=0)$ & + \\
\hline $\begin{array}{l}\text { Distance to the irrigation } \\
\text { scheme }\left(X_{9}\right)\end{array}$ & (Number in km) & - \\
\hline $\begin{array}{l}\text { Contact with extension } \\
\text { officers }\left(\mathrm{X}_{11}\right)\end{array}$ & Actual number of visits & + \\
\hline $\begin{array}{l}\text { Income from off/ non-farm } \\
\text { activities }\left(X_{12}\right)\end{array}$ & Amount in Rands (R) & + \\
\hline
\end{tabular}

\section{RESULTS AND DISCUSSION}

Descriptive statistics of the variables and the estimation results of the probit regression are presented to yield insights on the factors that influence the decision to adopt irrigation schemes.

\subsection{Demographic and socio-economic status of farmers}

Adopters were classified as farmers who were members of irrigation schemes and non-adopters are those who were not members of irrigation schemes during the years 2014 and 2015. The results show that $63 \%$ of the households were male headed. The average age was 60 years and there were no significant differences between the two groups in respect to age. The average household size was five persons. Education level of the household head was expressed as the number of years of schooling. The results indicated that the average number of years of schooling for the farmers in the sample was 7.25 years and there was no difference between 
S. Afr. J. Agric. Ext.

Vol. 47 No. 2, 2019: 94 - 104

http://dx.doi.org/10.17159/2413-3221/2019/v47n2a506
Christian, Obi

Agbugba

(License: CC BY 4.0)

the two groups. The average farming experience was 10.5 years. Adopters had more farming experience (11 years) than their counterparts (10 years).

There were significant differences in terms of access to credit between adopters and nonadopters. For example, the proportion of farmers reported to have access to credit in 2014/15 was significantly higher among adopters $(30.3 \%)$ than among non-adopters $(16.2 \%)$. The results also indicated that $47 \%$ of farmers were members of rural/ farmer associations. However, a significantly larger proportion of adopters (63\%) were members compared to $32 \%$ for non-adopters.

The pooled data shows that only $19.6 \%$ of the respondents in the study area accessed extension. This result suggests that respondents in the study area had difficulty in accessing government extension services and this might have a significant adverse impact on improving their level of production. It was also observed that irrigators had higher household off-farm incomes of R2 944 than for non-irrigators at R2 345.

Table 2: Demographic, institutional and socio-economic characteristics of members

\begin{tabular}{|c|c|c|c|c|}
\hline Variable & Description & Adopters & Non-Adopters & $\begin{array}{l}\text { Overall } \\
\text { sample }\end{array}$ \\
\hline & & Mean Value & Mean Value & $\begin{array}{l}\text { Average } \\
\text { Mean }\end{array}$ \\
\hline Age & Years & 62 & 58 & 60 \\
\hline Household size & $\begin{array}{l}\text { Number of } \\
\text { persons }\end{array}$ & 5.8 & 4.17 & 4.99 \\
\hline Level of education & Years in school & 7.3 & 7.2 & 7.25 \\
\hline $\begin{array}{c}\text { Farming } \\
\text { experience }\end{array}$ & Years in farming & 11 & 10 & 10.5 \\
\hline Off-farm income & In Rands & 2944.50 & 2345.79 & 2645.145 \\
\hline & & $\begin{array}{c}\text { Percentage } \\
(\%)\end{array}$ & $\begin{array}{c}\text { Percentage } \\
(\%)\end{array}$ & $\begin{array}{l}\text { Overall } \\
\text { sample }\end{array}$ \\
\hline \multirow{2}{*}{ Gender } & Male & 66 & 59 & 63 \\
\hline & Female & 34 & 41 & 37 \\
\hline \multirow{2}{*}{ Access to credit } & Yes & 30.3 & 16.2 & 23.25 \\
\hline & No & 69.7 & 83.8 & 76.75 \\
\hline \multirow{2}{*}{$\begin{array}{l}\text { Contact with } \\
\text { extension }\end{array}$} & Yes & 18.9 & 20.3 & 19.6 \\
\hline & No & 81.1 & 79.7 & 80.4 \\
\hline \multirow{2}{*}{$\begin{array}{l}\text { Member of society } \\
\text { group }\end{array}$} & Yes & 63 & 32 & 47.5 \\
\hline & No & 37 & 68 & 52.5 \\
\hline \multirow{2}{*}{$\begin{array}{c}\text { Farmers } \\
\text { perception about } \\
\text { irrigation }\end{array}$} & Positive & 98 & 28 & 63 \\
\hline & Negative & 2 & 72 & 37 \\
\hline \multirow{2}{*}{$\begin{array}{l}\text { Farmers attitude } \\
\text { towards irrigation }\end{array}$} & Good & 82 & 20 & 51 \\
\hline & Bad & 18 & 80 & 49 \\
\hline
\end{tabular}

Source: Field survey, 2015

From the discussions, the two groups of farmers had mixed perceptions with regards to irrigation schemes. For instance, $98 \%$ of adopters agreed that irrigation was good compared to 
S. Afr. J. Agric. Ext.

Vol. 47 No. 2, 2019: 94 - 104

http://dx.doi.org/10.17159/2413-3221/2019/v47n2a506
Christian, Obi

Agbugba

(License: CC BY 4.0)

$28 \%$ of non-adopters. Furthermore, the focus group discussions indicated that the adoption group unanimously accepted the need of irrigation to supplement rainfed agriculture. Adopting farmers had a positive attitude towards new technologies with the majority (82\%) being firsttime adopters. Only $18 \%$ had never applied the technology in the three years preceding the study. However, for non-adopters, only $20 \%$ indicated that they had adopted some of the technology, while as much as $80 \%$ had never adopted any technology, including irrigation technology.

\subsection{Modelling irrigation adoption decision}

The variables included in the model are age of the household head, gender of the household head, years of schooling, marital status, household size, farming experience, size of cultivated land, perceived land quality, mode of acquiring land, member of another community organisation, distance to the scheme, legibility to participate in scheme, access to extension services, access to market, and access to credit. The probit model was estimated to determine the household characteristics and resource endowments that affect farmers' adoption of irrigation technology. The results indicate that collectively, all estimated coefficients are statistically significant since the LR statistic has a $p$-value less than $1 \%$. The pseudo $\mathrm{R}$ value is $61 \%$ which is high for cross sectional data. The model also correctly predicted about $81 \%$ of the cases, confirming that the model fits the data well.

Table 3: Determinants of irrigation adoption decision

\begin{tabular}{|c|c|c|c|c|}
\hline Variables & Coefficients & Standard Error & $\mathbf{Z}$ & $\mathbf{P}>|\mathbf{z}|$ \\
\hline Constant & -1.003 & 2.309 & 0.367 & 0.664 \\
\hline Gender of HH head & -0.599 & 0.659 & 0.549 & 0.363 \\
\hline Age of $\mathrm{HH}$ head & 0.048 & 0.022 & 1.050 & $0.031 * *$ \\
\hline Level of education & 0.092 & 0.077 & 1.097 & 0.232 \\
\hline Household size & 0.123 & 0.111 & 1.131 & 0.267 \\
\hline Farming experience & 0.045 & 0.057 & 1.046 & 0.426 \\
\hline Farm size $(\mathrm{Ha})$ & 0.015 & 0.199 & 1.015 & 0.942 \\
\hline Access to extension & 0.677 & 1.666 & 1.968 & 0.684 \\
\hline Member of club & -4.250 & 1.687 & 70.117 & $0.012 * *$ \\
\hline Access to credit & 0.959 & 0.592 & 2.610 & $0.105^{*}$ \\
\hline Access to market & 1.078 & 0.899 & 2.940 & $0.130 *$ \\
\hline $\begin{array}{l}\text { Distance to the } \\
\text { scheme }\end{array}$ & -0.341 & 0.067 & 0.711 & $0.000 * * *$ \\
\hline \multirow{2}{*}{\multicolumn{2}{|c|}{ Probit model }} & \multicolumn{2}{|c|}{ Number of Observ $=$} & 200 \\
\hline & & \multicolumn{2}{|c|}{ Prob $>\mathrm{Chi}^{2}=$} & 0.000 \\
\hline \multicolumn{2}{|c|}{ Log likelihood $=88.961$} & \multicolumn{2}{|c|}{ Pseudo $\mathrm{R}^{2}=$} & 0.813 \\
\hline
\end{tabular}

Note: $* * *, * *$ and $*$ means significant at $1 \%, 5 \%$ and $10 \%$ levels, respectively.

Source: Results from SPSS (Version 20) generated from field survey, 2015

The estimates indicate that age of the household head significantly influenced adoption at the $5 \%$ level, suggesting that an increase in age leads to a possible 3\% increase in irrigation adoption. These results closely mirror Daniel (2011) and Salome and Rotimi (2013) who established that age was significant in the household head decision to adopt new technologies. 
S. Afr. J. Agric. Ext.

Vol. 47 No. 2, 2019: 94 - 104

http://dx.doi.org/10.17159/2413-3221/2019/v47n2a506
Christian, Obi

Agbugba

(License: CC BY 4.0)

On the contrary, a study by Mattee and Gebreyes (2013) indicated that younger household heads are more innovative in terms of technology participation and are more likely to take risks than older household heads.

Access to credit had a positive and statistically significant effect on adoption at the $10 \%$ significance level, suggesting that farmers who could easily access credit have a greater likelihood of adopting. Access to credit support ensures that farmers can secure inputs in time, resulting in increased farm income. Adoption of irrigation technology is also associated with the use of a range of complementary inputs that are sourced through the market. Machete et al (2004) suggest that one of the most critical problems threatening the viability of irrigation is the lack of credit to meet the additional cash obligations of technology adopting farmers. The results agree with the findings of Daniel (2011) that access to credit plays an important role in improving household livelihoods.

Distance to irrigation schemes significantly influences the decision to adopt. However, the relationship is negative, which means that the further the households are from the scheme, the less likely they are to participate as compared to households that are located within a close proximity. As the distance from a scheme increases by one kilometre, household participation declines. In this study, results suggest that a decline in participation of up to $34 \%$ can be observed. In contrast, Asayehegn et al (2011) found that distance had no impact on participation in Ethiopia.

Moreover, membership of farmer groups had a significantly negative effect on adoption. The decision to adopt irrigation by households who are members of other community groups was less. This is an important finding considering the infrastructure situation in many communities and the fact that most schemes are known to draw clientele from residents in their immediate vicinities while the rest of the communities are virtually isolated. A scheme in the neighbourhood has a demonstration effect which will produce positive responses from farmers.

\section{CONCLUSION AND RECOMMENDATIONS}

Smallholder farmers in the Eastern Cape could potentially contribute to economic growth and development, but this depends crucially on the extent of technology use, among other factors. The revitalisation of small-scale irrigation schemes undertaken early in the reform era was expected to enhance agricultural production, yet adoption of the technology has been limited which is probably due to a range of institutional, technical and socio-economic constraints. The finding that distance to irrigation schemes negatively influences adoption of irrigation technology is an important one. At one level, it reflects the infrastructure profile of much of the rural Eastern Cape where locational constraints are sometimes severe to the point of communities being isolated and virtually excluded from civilisation. At another level, it is one factor that is amenable to policy intervention since it is possible to do something about where a scheme is located. Furthermore, the distance to a scheme will affect other factors, particularly extension access as well as credit access, both of which individually and collectively have important practical implications for technology adoption. As the current debate on agricultural restructuring rages, it is important to pay attention to these relationships to the extent that technology adoption is crucial to the agricultural transformation process and is crucial to the attainment of food security and improvement of rural livelihoods through poverty reduction. 
S. Afr. J. Agric. Ext.

Vol. 47 No. 2, 2019: 94 - 104

http://dx.doi.org/10.17159/2413-3221/2019/v47n2a506
Christian, Obi

Agbugba

(License: CC BY 4.0)

\section{ACKNOWLEDGEMENTS}

The research was funded by the Water Research Commission while the first author's living expenses were covered under a DAAD-NRF bursary. The authors are grateful to these organisations and to the farmers, district agriculture office workers, and all those who participated in the data collection and analysis.

\section{REFERENCES}

ASAYEHEGN, K., YIRGA, C. \& RAJAN., S., 2011. Effect of small-scale irrigation on the income of rural farm households: The case of Laelay Maichew District, Central Tigray, Ethiopia. J. Stored Prod. Postharvest Res., 2(10):208-215.

BACKEBERG, G.R. \& SANEWE, A.J., 2006. The research and development strategy for water utilisation in agriculture-responding to diverse needs of farmers in South Africa. Irrig. Drain., 55(3):281-290.

DANIEL, S., 2011. The role of the International Finance Corporation in promoting agricultural investment and large-scale land acquisitions. Paper presented to The International Conference on Global Land Grabbing. Sussex, England.

DELGADO, C., 1999. Sources of growth in smallholder agriculture in sub-Saharan Africa: The role of vertical integration of smallholders with processors and marketers of high value-added items. Agrekon, 38:165-89.

DENISON, J. \& MANONA, S., 2007. Principles, approaches and guidelines for the participatory revitalisation of smallholder irrigation schemes: A rough guide for irrigation development practitioners. WRC Report No. TT,309. Pretoria, South Africa.

DEPARTMENT OF WATER AFFAIRS, 2013. National water policy review: Updated policy positions to overcome the water challenges of our developmental state to provide for improved access to water, equity and sustainability. Pretoria, South Africa.

DERCON, S., 2004. Growth and shocks: Evidence in rural Ethiopia. J. Dev. Econ., 74(2):309329.

FREEMAN, H.A. \& SILIM, S.S., 2001. Commercialisation of smallholder irrigation: The case of horticultural crops in semi-arid areas of Eastern Kenya. In Proceedings of Regional Seminar on Private Sector Participation and Irrigation Expansion in sub-Saharan Africa, pp.185-191.

GIBB, A., 2004. Principles, approaches and guidelines for participatory revitalisation of smallholder irrigation schemes. Report No. K5,1463,4. East London, South Africa.

GUJARATI, D., 2004. Basic Econometrics. $4^{\text {th }}$ ed. McGraw-Hill.

JACOBS, P., 2010. Household food insecurity, rapid food price inflation and the economic downturn in South Africa. Agenda, 24(86):38-51.

KODUA-AGYEKUM, C., 2009. The transfer of technology to the rural poor: The case of Qamata Irrigation Scheme in the Eastern Cape Province of South Africa. PhD Thesis, University of Kwazulu-Natal.

LIPTON, M., 1996. Land, Labour and Livelihoods in Rural South Africa. Durban: Indicator Press. 
S. Afr. J. Agric. Ext.

Vol. 47 No. 2, 2019: 94 - 104

http://dx.doi.org/10.17159/2413-3221/2019/v47n2a506
Christian, Obi

Agbugba

(License: CC BY 4.0)

MACHETE, C.L., MOLLEL, N.M., AYISI, K., MASHATOLA, M.B., ANIM, F.D.K. \& VANASSCHE, F., 2004. Smallholder irrigation and agricultural development in the Olifants River Basin of Limpopo Province: Management transfer, productivity, profitability and food security issues. WRC Report No. 1050,1,04. Pretoria, South Africa.

MATTEE, A.Z. \& GEBREYES, M.G. 2013. Nature and Cost of Participation in Farmer Field Schools. Case Study of North Wollo Administration Zone, Ethiopia. Article in the Journal of Continuing Education and Extension, 4(1):116-117.

MUCHARA, B., 2011. Analysis of food value chains in smallholder crop and livestock enterprises in the Eastern Cape Province of South Africa. MSc Thesis, University of Fort Hare.

RIBOT, J.C. \& PELUSO, N.L., 2003. A theory of access. Rural Sociol., 68(2):153-181.

SALOME, E.N. \& ROTIMI, O., 2013. Implications of training and development programmes on accountants' productivity in selected business organizations in Onitsha, Anambra State, Nigeria. Int. J. Asian Soc. Sci., 3(1):266-281.

SEN, A., 1981. Poverty and famines: An essay on entitlement and deprivation. Oxford: Clarendon Press.

SISHUTA, B., 2005. Small-scale irrigation development for sustainable rural development: A case study of the Tyhefu Irrigation Scheme. Afr. Sociol. Rev., 9(2):184-206.

STATISTICS SOUTH AFRICA, 2008. Quarterly labour force survey quarter 3. Pretoria, South Africa.

TURRAL, H., SVENDSEN, M. \& FAURES, J.M., 2010. Investing in irrigation: Reviewing the past and looking to the future. Agric. Water Manag., 97(4):551-560.

VAN AVERBEKE \& MOHAMMED, S.S., 2006. Smallholder farming styles and development policy in South Africa: The Dzindi Irrigation Scheme. Agrekon, 45(2):136157. 
